\title{
On-site and ground-based remote sensing measurements of methane emissions from four biogas plants: a comparison study
}

Fredenslund, Anders Michael; Hinge, Jørgen; Holmgren, Magnus A.; Rasmussen, Søren G.; Scheutz, Charlotte

\section{Published in:}

Bioresource Technology

Link to article, DOI:

10.1016/j.biortech.2018.08.080

Publication date:

2018

Document Version

Peer reviewed version

Link back to DTU Orbit

\section{Citation (APA):}

Fredenslund, A. M., Hinge, J., Holmgren, M. A., Rasmussen, S. G., \& Scheutz, C. (2018). On-site and groundbased remote sensing measurements of methane emissions from four biogas plants: a comparison study. Bioresource Technology, 270, 88-95. https://doi.org/10.1016/j.biortech.2018.08.080

\section{General rights}

Copyright and moral rights for the publications made accessible in the public portal are retained by the authors and/or other copyright owners and it is a condition of accessing publications that users recognise and abide by the legal requirements associated with these rights.

- Users may download and print one copy of any publication from the public portal for the purpose of private study or research.

- You may not further distribute the material or use it for any profit-making activity or commercial gain

- You may freely distribute the URL identifying the publication in the public portal 


\section{Accepted Manuscript}

On-site and ground-based remote sensing measurements of methane emissions from four biogas plants: a comparison study

Anders M. Fredenslund, Jørgen Hinge, Magnus A. Holmgren, Søren G.

Rasmussen, Charlotte Scheutz

PII:

S0960-8524(18)31184-2

DOI: https://doi.org/10.1016/j.biortech.2018.08.080

Reference:

BITE 20363

To appear in:

Bioresource Technology

Received Date:

15 June 2018

Revised Date:

17 August 2018

Accepted Date:

18 August 2018

Please cite this article as: Fredenslund, A.M., Hinge, J., Holmgren, M.A., Rasmussen, S.G., Scheutz, C., On-site and ground-based remote sensing measurements of methane emissions from four biogas plants: a comparison study, Bioresource Technology (2018), doi: https://doi.org/10.1016/j.biortech.2018.08.080

This is a PDF file of an unedited manuscript that has been accepted for publication. As a service to our customers we are providing this early version of the manuscript. The manuscript will undergo copyediting, typesetting, and review of the resulting proof before it is published in its final form. Please note that during the production process errors may be discovered which could affect the content, and all legal disclaimers that apply to the journal pertain. 


\title{
On-site and ground-based remote sensing measurements of methane emissions
}

\section{from four biogas plants: a comparison study}

Anders M. Fredenslund ${ }^{\mathrm{a}}$, Jørgen Hinge ${ }^{\mathrm{b}}$, Magnus A. Holmgren ${ }^{\mathrm{c}}$, Søren G. Rasmussen ${ }^{\mathrm{b}}$, Charlotte Scheutz $z^{\mathrm{a}}$

${ }^{a}$ Department of Environmental Engineering, Technical University of Denmark, 2800 Kongens Lyngby, Denmark

b Teknologisk Institut AgroTech, Agro Food Park 15, 8200 Aarhus N, Denmark

${ }^{\mathrm{c}}$ RISE, Industrigatan 4, 50462 Borås, Sweden

\section{Keywords}

Fugitive methane emissions, tracer gas, greenhouse gases, anaerobic digestion

\begin{abstract}
Methods for quantifying methane $\left(\mathrm{CH}_{4}\right)$ emissions from biogas plants are needed, in order to ensure that emissions are within acceptable levels and to identify options for emission mitigation. Two emission measuring approaches were used at four biogas plants: an on-site approach, whereby emission sources were identified and subsequently quantified one at a time, and a ground-based remote sensing approach, which was applied to measure total $\mathrm{CH}_{4}$ emissions. The emissions were between 5.5 to $13.5 \mathrm{~kg} \mathrm{CH}_{4} \mathrm{~h}^{-1}$ from the four plants, measured using ground-based remote sensing. Even though the measurements were performed on the same days at each facility, the sum of on-site emission rates varied between the remote sensing measurements (up to $\sim 100 \%$ ). Several factors may have caused this difference: emission sources not measured using an on-site approach and
\end{abstract}


short-time emission variation. On-site measurements showed that the majority of the emissions often occurred from just a few sources.

\section{Keywords}

Method comparison, anaerobic digestion, fugitive emissions, tracer gas dispersion method.

\section{Introduction}

Methane gas $\left(\mathrm{CH}_{4}\right)$ is an important fuel used for electricity production, heating and transportation purposes. Most of the $\mathrm{CH}_{4}$ used for fuel purposes today originates from natural gas. In transitioning away from the use of fossil fuels, biogas plants may provide a valuable alternative, thereby reducing greenhouse gas (GHG) emissions through fossil fuel substitution. The anaerobic digestion of animal slurry also reduces $\mathrm{CH}_{4}$ emissions from manure storage (Clemens et al., 2006; Sommer et al., 2004), and so biogas production has several GHG mitigation effects.

$\mathrm{CH}_{4}$ emissions from biogas plants reduce net GHG benefits. Data on the magnitude of these emissions are sparse, though, so there is some uncertainty with regards to the environmental assessment of biogas production vis-à-vis global warming (Meyer-Aurich et al., 2012; Møller et al., 2009).

In one case study, using an inverse dispersion measuring technique over four campaigns, average $\mathrm{CH}_{4}$ emissions from an agricultural anaerobic digester were $3.1 \%$ of gas production (Flesch et al., 2011). The inverse dispersion method involves downwind, cross-plume measurements of atmospheric $\mathrm{CH}_{4}$ concentrations, wind measurements and dispersion modelling, to estimate $\mathrm{CH}_{4}$ emission rates. $\mathrm{CH}_{4}$ emission rates from the digester were found to vary, seemingly according to operational conditions at the facility, where periods of relatively high emissions occurred during periods of biogas flaring (Flesch et al., 2011). Using a similar measurement methodology in another 
study, $\mathrm{CH}_{4}$ emission rates measured for a German digester varied between 7.2 and $57.6 \mathrm{~kg} \mathrm{CH}_{4} \mathrm{~h}^{-1}$ (or between 3 and $23 \%$ of gas production) over a period of little more than two hours (Groth et al., 2015). The highest emission rates coincided with opening the digester's pressure relief valve, while during normal operation, the $\mathrm{CH}_{4}$ emission rate averaged $4 \%$ of production. Similarly, Reinelt et al. (2016) found pressure relief valves to be important sources of $\mathrm{CH}_{4}$ emissions at two biogas plants. Furthermore, Liebetrau et al. (2013) monitored $\mathrm{CH}_{4}$ emissions from 10 German biogas plants, where individual leaks were first identified and subsequently quantified using a variety of techniques, including chamber measurements. It was established that open digestate storage tanks and cogeneration units are important sources of $\mathrm{CH}_{4}$ emissions - a finding supported by Baldé et al. (2016)'s study, in which $\mathrm{CH}_{4}$ discharges from an open digestate storage unit were monitored over a two-year period, with emissions corresponding to $12 \%$ of biogas production.

A comparative measurement campaign was performed at a biogas plant, using several on-site and remote sensing methods simultaneously to determine $\mathrm{CH}_{4}$ loss, by four on-site measurement teams and two remote sensing teams (Reinelt et al., 2017). In that study, large but short-term variations in emission rates were observed, and $\mathrm{CH}_{4}$ emission rates varied between 5 and $25 \mathrm{~kg} \mathrm{CH}_{4} \mathrm{~h}^{-1}$ (remote sensing measurements) and 5 and $17 \mathrm{~kg} \mathrm{CH}_{4} \mathrm{~h}^{-1}$ (on-site measurements). These variations were explained as resulting partly from changes in the operational state of the biogas plant, and the main sources of emissions were found to be an open digestate storage tank and a pressure release valve (Reinelt et al., 2017). Unfortunately, on-site and remote sensing measurements were not done on the same days, and so the paper recommended that future measurement studies comparing on-site and remote sensing measurements should be carried out simultaneously.

In this paper, we used on-site measuring methods to quantify $\mathrm{CH}_{4}$ emissions from four Danish biogas plants, combined with measurements of total $\mathrm{CH}_{4}$ emissions from the plants using a ground- 
based remote sensing technique. At each plant, one measurement team measured one source at a time, while another team used a remote sensing method on the same day.

\section{Materials and methods}

\subsection{Site descriptions}

\subsubsection{Biogas plant $A$}

Biogas plant $\mathrm{A}$ is a centralised, agricultural-based plant utilising $\sim 225,000$ tons $\mathrm{yr}^{-1}$ biomass to produce $\sim 3.4$ million $\mathrm{kg} \mathrm{CH}_{4} \mathrm{yr}^{-1}$ of biogas. Feedstocks include manure $(\sim 85 \% \mathrm{w} / \mathrm{w})$ as well as organic, industrial surplus such as slaughterhouse waste. The biogas plant was constructed in 19891990, and a major reinvestment was executed in 2013-2014 to modernise the facility and to expand production capacity. The biogas plant has four continuously stirred reactors (CSTRs) with a combined volume of $12,950 \mathrm{~m}^{3}$. All digestion units are operated at a thermophilic temperature $\left(52^{\circ} \mathrm{C}\right)$ and are made of steel. There are also five biomass storage and pre-treatment tanks with a total volume of $3300 \mathrm{~m}^{3}$. The biogas is used in a combined heat and power (CHP) unit at the site $(1.35 \mathrm{MW})$ and in two CHP units $(2 \times 2.65 \mathrm{MW})$ at a power plant off-site (Table 1$)$. All CHP units are gas engines. The digestate is stored in a $4300 \mathrm{~m}^{3}$ closed concrete tank with gas collection and an integrated $3500 \mathrm{~m}^{3}$ gas storage. Other parts of the biogas plant include a $200 \mathrm{~m}^{3}$ closed mixing tank, a $1500 \mathrm{~m}^{2}$ dry biomass storage building, two gas bag type, double membrane biogas storage units (combined volume: $4500 \mathrm{~m}^{3}$, operated at slight overpressure), a gas flare and a180 $\mathrm{m}^{2}$ biofilter for odour reduction with a capacity of $22,000 \mathrm{~m}^{3}$ air $\mathrm{h}^{-1}$. The mixing tank and dry biomass storage were covered, but not gas tight. No measurement of $\mathrm{CH}_{4}$ emissions from the facility had been performed prior to this study. Leakage from the gas storage unit was suspected by the plant operator prior to the measurement campaign.

\subsubsection{Biogas plant $B$}


Biogas plant B utilises sludge from wastewater treatment to produce $\sim 1.4$ million $\mathrm{kg} \mathrm{CH}_{4} \mathrm{yr}^{-1}$ of biogas, and it is a part of a wastewater treatment facility receiving wastewater from 265,000 people. The facility was constructed in 1965 and then expanded and renovated in 1995. It has four CSTRs made of concrete with a total volume of $24,000 \mathrm{~m}^{3}$. Digestate is led to four $250 \mathrm{~m}^{3}$ open storage tanks, and the digestate is de-watered and incinerated. The biogas is utilised in an on-site CHP unit (gas engine). Other parts of the biogas plant include a gas bag type biogas $1400 \mathrm{~m}^{3}$ storage unit and a gas flare. Total $\mathrm{CH}_{4}$ emissions had previously been measured at the facility, using the same measurement method and equipment as in this study (Yoshida et al., 2014). Emissions were found to vary significantly between the nine performed measurement campaigns. Short-term variations in emissions (i.e. variations during measurement campaigns) were also observed. Measured total $\mathrm{CH}_{4}$ emissions were between $5 \mathrm{~kg} \mathrm{CH}_{4} \mathrm{~h}^{-1}$ and $92 \mathrm{~kg} \mathrm{CH}_{4} \mathrm{~h}^{-1}$, with the highest emission rates observed during foaming events in the digesters. The biogas plant was found to be the most significant source of $\mathrm{CH}_{4}$ emission compared to other parts of the wastewater treatment facility such as aeration tanks and primary/secondary clarifiers.

\subsubsection{Biogas plant $\mathrm{C}$}

Biogas plant $\mathrm{C}$ is a centralised, agricultural-based biogas plant utilising $\sim 240,000$ tons $\mathrm{yr}^{-1}$ biomass to produce $\sim 4.6$ million $\mathrm{kg} \mathrm{CH}_{4} \mathrm{yr}^{-1}$ of biogas, which is upgraded to bio-methane on the site, using a water scrubber. No post-treatment of the upgrading exhaust was present. Feedstocks include manure and slaughterhouse waste. The biogas plant was constructed in 2013-2014, and at the time of this study it was being expanded - including the installation of a new biogas upgrade facility, due to increased production. It has three continuously stirred $800 \mathrm{~m}^{3}$ CSTRs (step 1) and a $2200 \mathrm{~m}^{3}$ CSTR (step 2). The reactors are closed steel tanks. Digestate is stored in two closed concrete tanks with gas collection with a combined storage capacity of $2200 \mathrm{~m}^{3}$. Other parts of the biogas plant include a mixing tank, a biomass hygienisation unit, a biological odour reduction unit and a gas flare. The 
upgraded bio-methane is injected into the natural gas grid. $\mathrm{No}_{\mathrm{CH}}$ emission measurements had been performed prior to this study. Staff at the facility performs weekly visual inspections of the installations, to reduce gas leakage. The operator of the facility suspected the biogas upgrade facility to be emitting $\mathrm{CH}_{4}$ at the time of measurement, since its production had exceeded the designed capacity of the upgrade unit.

\subsubsection{Biogas plant D}

Plant D is also a centralised, agricultural-based facility and utilises $\sim 118,000$ tons $\mathrm{yr}^{-1}$ biomass to produce $\sim 2.9$ million $\mathrm{kg} \mathrm{CH}_{4} \mathrm{yr}^{-1}$ of biogas. Feedstocks include manure $(\sim 85 \% \mathrm{w} / \mathrm{w})$, straw and maize silage. The biogas plant was constructed in 2014 to operate as a two-step system, where most of the gas production occurs in two CSTRs with a combined volume of $9200 \mathrm{~m}^{3}$. From these tanks, the biomass is pumped into two secondary digesters, which also have a combined volume of 9200 $\mathrm{m}^{3}$. All reactors are made of concrete and have double-walled, insulated soft covers. Digestate is stored in three storage tanks equipped with stirrers, with a collective total volume of $13,800 \mathrm{~m}^{3}$. The digestate storage tanks are also made of concrete and have double-walled, insulated soft covers and gas collection. The biogas plant operates at a thermophilic temperature $\left(54{ }^{\circ} \mathrm{C}\right)$, and biogas is upgraded to bio-methane, using chemical absorption in an on-site amine scrubber unit, which is then injected into the natural gas grid. Other parts of the biogas plant include walled bunker silos for maize silage, a mixing tank, a gas flare, an odour reduction unit (biofilter) and a biomass storage building. The biofilter is a two-stage system designed to treat $15,000 \mathrm{~m}^{3}$ air $\mathrm{h}^{-1}$. The first stage (69 $\mathrm{m}^{2}$ ) contains calcareous materials to reduce hydrogen sulphide emissions. The second, main stage $\left(115 \mathrm{~m}^{2}\right)$ contains a mixture of compost and lightweight clay aggregate. $\mathrm{No}_{\mathrm{CH}}$ measurement had been performed prior to this study. Staff at the facility performs inspections of the installations to counter gas leakage. 


\subsection{Remote sensing - the tracer gas dispersion method}

Total $\mathrm{CH}_{4}$ emission rates from the biogas plants were determined using a tracer gas dispersion method (TDM) (Delre et al., 2018; Mønster et al., 2015, 2014; Yoshida et al., 2014). The TDM involves the continuous release of a gaseous tracer combined with downwind measurements of atmospheric $\mathrm{CH}_{4}$ and tracer gas, performed while traversing the plume and using a mobile analytical platform. In the measurements reported herein, acetylene $\left(\mathrm{C}_{2} \mathrm{H}_{2}\right)$ was used as tracer gas. The emission rate of the target gas $\left(\mathrm{CH}_{4}\right.$ in this case $)$ can be determined using Eq. 1:

$$
E_{\text {target }}=Q_{\text {tracer }} \times \frac{\int_{\text {Plume end }}^{\text {Plurt }}\left(C_{\text {target }}-C_{\text {target }, \text { background }}\right) d x}{\int_{\text {Plume start }}^{\text {Plume }}\left(C_{\text {tracer }}-C_{\text {tracer }, \text { background }}\right) d x} \cdot \frac{M W_{\text {target }}}{M W_{\text {tracer }}}
$$

where $\mathrm{E}_{\text {target }}$ is the target gas emission (here $\left.\mathrm{CH}_{4}\right), \mathrm{Q}_{\text {tracer }}$ is the release rate of the tracer gas $\left(\mathrm{kg} \mathrm{h}^{-1}\right)$, $\mathrm{C}_{\text {target }}$ and $\mathrm{C}_{\text {tracer }}$ are concentrations of target and tracer gas (ppbv) above background level, $\mathrm{MW}_{\text {target }}$ and $\mathrm{MW}_{\text {tracer }}$ are the molecular weights of the target and tracer gas and $\mathrm{x}$ is the distance across the plume (m). The measurements were conducted by driving multiple times through the downwind plume, and emission rates were calculated using Eq. 1 for each plume traverse and then calculated as the average of all traverses in the campaigns, thereby giving a plant-integrated emission rate for the duration of the performed measurements. Uncertainties relating to the measured emission rates were estimated as the standard error of the mean (sample standard deviation of the $\mathrm{CH}_{4}$ emission rates calculated for each plume traverse, divided by the square root of the number of plume traverses).

Measurements of the target and tracer gas concentrations were performed using a cavity ring-down spectrometer (G2203, Picarro Inc., USA), installed in a vehicle, and from where atmospheric gas was pumped into the analyser from an intake placed on the roof of the vehicle. The measurement frequency of the instrument was $\sim 1 \mathrm{~Hz}$, and the precision of the $\mathrm{CH}_{4}$ and $\mathrm{C}_{2} \mathrm{H}_{2}$ measurements was 
$0.77 \mathrm{ppb}$ and $0.06 \mathrm{ppb}$, respectively $(1 \sigma, 1$ hour $)$. A monitor in the driver's cabin displayed realtime concentration data as they were recorded. A global navigation satellite system (GNSS) receiver was used to log the positions of the measurements (an R330 GNSS receiver and an A43 antenna, Hemisphere, Canada).

Initial emission screenings were performed in each case, to identify the main $\mathrm{CH}_{4}$ emissions areas at the biogas plants as well as in the surrounding area, in order to establish from where tracer gas would be released and to evaluate if any other nearby $\mathrm{CH}_{4}$-emitting sources (farms, wastewater treatment plants, etc.) could affect the measurements.

Tracer gas was released from one or two locations at the biogas plants at release rates of between 0.6 and $0.9 \mathrm{~kg} \mathrm{C}_{2} \mathrm{H}_{2} \mathrm{~h}^{-1}$ in total. $\mathrm{C}_{2} \mathrm{H}_{2}$ flow was measured using $150 \mathrm{~mm}$ variable-area flowmeters (Sho-Rate, Brooks Instruments, Holland) calibrated for measuring between 0 and $1.65 \mathrm{~kg} \mathrm{C}_{2} \mathrm{H}_{2}$ per minute and with an uncertainty of $5 \%$ on the maximum value.

\subsection{On-site methods}

\subsubsection{Leakage detection}

At each biogas plant, on-site measurements were initiated by performing a leak search. At biogas plants A, B and D, this was done with an optical gas imaging infrared (IR) video camera (GF 320, FLIR, Wilsonville, USA), which was used to inspect all biogas-bearing plant components (digesters, storage tanks, gas pipes, biomass pipes, valves, gas storage units, etc.). The IR camera visualises biogas emitted from a source as a grey-coloured cloud, and it can be used to sense leaks remotely from pipes, tanks, valves etc. and in hard to access areas. The camera was adjusted to wavelengths between 3.2 and $3.4 \mu \mathrm{m}$, thereby allowing it to detect a range of hydrocarbons including $\mathrm{CH}_{4}$. The IR camera has a detection limit of $\sim 8-9 \mathrm{~L} \mathrm{CH}_{4} \mathrm{~h}^{-1}$ in laboratory conditions (pure 
$\mathrm{CH}_{4}, \sim 2 \mathrm{~m} \mathrm{~s}^{-1}$ wind speed, $3 \mathrm{~m}$ distance to source) (Reinelt et al., 2017). A potential advantage of this leakage detection method is the capability of detection of emission sources at a distance (and thus also at hard to access areas) without the need to sample the emitting gas.

At biogas plant $\mathrm{C}$, the leak search was performed with a portable $\mathrm{CH}_{4}$ analyser (EX-TEC PM4, Sewerin, Gütersloh, Germany) equipped with a semiconductor sensor detecting flammable gases, including $\mathrm{CH}_{4}$ in the ppm range. A potential advantage of this leakage detection method is high portability and ease of use inside buildings. The $\mathrm{CH}_{4}$ analyser leak search was supplemented with leak search using an optical gas imaging camera of the same make and model as described above.

The reason behind the different methodology used at biogas plant $\mathrm{C}$ was that the on-site measurements at that site were performed by a different measurement team with a partially different set of equipment's than the team at plants A, B and D.

\subsubsection{Emission quantification, using a high-volume sampling technique}

A high-volume sampling technique was used to quantify identified gas leakages on digesters, biomass storage tanks, gas storage units, etc. This method involved collecting the leaking gas, using a sampling hood modified to cover partly the leak in each case. The sampling hood was connected to an ATEX proof blower (MSX 200-3, GEOVENT A/S, Denmark) via a hose. $\mathrm{CH}_{4}$ concentration in the air/biogas mixture was determined using either a photoacoustic gas analyser (INNOVA 1412, Lumasense Technologies, USA) or a tuneable diode laser $\mathrm{CH}_{4}$ analyser (LGD F200A, Axetris, Switzerland). The flow rate of the air/biogas mixture was measured by analysing pressure differences with a calibrated orifice (FMU, Lindab GmbH, Germany) and a pressure sensor (2020P7, Digitron, UK). The flow rates were calculated using Eq. 2: 
$Q_{\text {air }}=C \cdot A_{2} \sqrt{\frac{2\left(P_{1}-P_{2}\right)}{\rho\left(1-\left(\frac{A_{2}}{A_{1}}\right)^{2}\right)}}$

where $Q_{\text {air }}$ is the flowrate of air $\left(\mathrm{m}^{3} \mathrm{~h}^{-1}\right), \mathrm{C}$ is an orifice flow coefficient (dimensionless), $\mathrm{A}_{1}$ is the cross-sectional area of the hose $\left(\mathrm{m}^{2}\right), \mathrm{A}_{2}$ is the cross-sectional area of the calibrated orifice $\left(\mathrm{m}^{2}\right), \mathrm{P}_{1}$ is upstream pressure $(\mathrm{Pa}), \mathrm{P}_{2}$ is downstream pressure $(\mathrm{Pa})$ and $\rho$ is air density $\left(\mathrm{kg} \mathrm{m}^{-3}\right)$.

$\mathrm{CH}_{4}$ emissions were determined using Eq. 3:

$E_{C H 4}=Q_{\text {air }} \cdot \rho_{C H 4}\left(C_{C H 4, \text { out }}-C_{C H 4, \text { in }}\right)$

where $\mathrm{E}_{\mathrm{CH} 4}$ is the $\mathrm{CH}_{4}$ emission mass flow $\left(\mathrm{g} \mathrm{h}^{-1}\right)$, $\mathrm{Q}_{\text {air }}$ is the volume air flow $\left(\mathrm{m}^{3} \mathrm{~h}^{-1}\right), \rho_{\mathrm{CH} 4}$ is the gas density of $\mathrm{CH}_{4}\left(\mathrm{~g} \mathrm{~m}^{-3}\right)$ and $\mathrm{C}_{\mathrm{CH} 4 \text {,out }}$ and $\mathrm{C}_{\mathrm{CH} 4 \text {,in }}$ are exhaust and background $\mathrm{CH}_{4}$ concentrations, respectively (molar fractions).

\subsubsection{Emission quantification from active ventilation units (ducts and pipes)}

Quantifying $\mathrm{CH}_{4}$ emissions from active ventilation units was done by measuring the air flow through the ventilation system as well as the concentration of $\mathrm{CH}_{4}$ in the ventilation air. By multiplying the air flows with $\mathrm{CH}_{4}$ concentrations above background levels measured near the biogas plants, $\mathrm{CH}_{4}$ emission rates through these units were determined. The air flows were either measured by using a pitot tube/micro manometer (Mano-Air 100, Schiltknecht, Switzerland) according to the standard "DS/EN ISO 16911-1 Manual and automatic determination of velocity and volume flow rate in ducts - Part 1: Manual reference method" or were determined according to the ventilation units' technical specifications. $\mathrm{CH}_{4}$ concentrations were measured using the photoacoustic gas analyser mentioned above, a tuneable diode laser or a flame ionisation detector (FID) equipped with a non-methane hydrocarbon cutter (3-900, J.U.M. Engineering GmbH, Germany). 


\subsubsection{Emission quantification from open digestate storage}

Biogas plant B was the only facility in this study with open tanks for digestate storage. Capacity was relatively low (retention time: $\sim 12 \mathrm{~h}$ ), since the digestate from these tanks was dewatered and incinerated at the facility. Results from the leakage detection at biogas plant B suggested that the open digestate storage was a significant contributor to $\mathrm{CH}_{4}$ emission, but the on-site measurement team was not equipped to quantify this source through measurement. This $\mathrm{CH}_{4}$ emission was instead estimated by assuming that $\mathrm{CH}_{4}$ formation in the open digestate storage units was similar to $\mathrm{CH}_{4}$ formation $\left(\sim 6.7 \mathrm{~g} \mathrm{CH}_{4} \mathrm{~m}^{-3}\right.$ digestate $\left.\mathrm{h}^{-1}\right)$ in the digesters, due to the $\sim 12 \mathrm{~h}$ retention time, and that this $\mathrm{CH}_{4}$ would emit from the digestate storage unit.

\subsubsection{Emission quantification via the CHP units}

$\mathrm{CH}_{4}$ emissions from $\mathrm{CHP}$ units were not measured by the on-site teams, since they were beyond the scope of the project, which results are discussed here. However, to compare emission rates measured by on-site teams to the remote sensing results, we used typical emission figures for gas engines, to provide suitable estimates.

$\mathrm{CH}_{4}$ emissions from the CHP units at biogas plants A and B were estimated by multiplying gas consumption from the engines with an assumed $\mathrm{CH}_{4}$ emission of $1.5 \%$ of consumed $\mathrm{CH}_{4}$ fuel. This value was converted from an emission factor of $300 \mathrm{~g} \mathrm{CH}_{4} \mathrm{GJ}^{-1}$ for biogas engines listed by the Danish Energy Agency (Energistyrelsen and Energinet.dk, 2017), which is close to the average measured losses from biogas engines (1.7\% of consumed $\mathrm{CH}_{4}$ fuel) (Liebetrau et al., 2013). We note that $\mathrm{CH}_{4}$ emissions from biogas engines are known to vary. In Liebetrau et al. (2013) emissions from eight gas engines were measured, and the emissions ranged from 0.4 to $3.3 \%$ of $\mathrm{CH}_{4}$ consumption. Using a fixed factor to estimate $\mathrm{CH}_{4}$ emissions from specific gas engines as done here may therefore be more uncertain compared to measurements. 


\subsection{Measurement campaigns}

TDM and on-site measurements were performed at each of the four biogas plants on the same measurement days by two teams working independently between October 26, 2015 and Nov. 5, 2015. For biogas plant A, the measurements spanned over two working days, since the on-site measurements could not be completed on the first day, whereas measurements for plants B, C and D were completed over one working day. At each facility, the on-site team started their work by identifying leaks, and then they used the remaining time to measure emission rates from each of the identified leaks one at a time. Limitations due to weather conditions and the physical surroundings of the plants meant that it was only possible to perform TDM measurement part of the time while on-site measurements were performed.

Measurements and data analysis, including the calculation of emission rates and reporting, were done independently by the TDM and on-site teams. The results were reported by each team to the project leader, without one team knowing the results of the other team.

\section{Results and discussion}

\subsection{Methane emissions from biogas plant A}

At biogas plant A, measurements spanned over two days, since the facility was large and numerous sources of $\mathrm{CH}_{4}$ emission were identified using an optical imaging leakage search. In total, 22 individual sources of $\mathrm{CH}_{4}$ emission were found, some of which were quantified together; two leaks, for example, were found at two gas pipes (from a pipe joint and a valve) located inside a gas building, quantified by measuring the $\mathrm{CH}_{4}$ flow $\left(\mathrm{CH}_{4}\right.$ concentration and air flow) through the building's ventilation system and thus resulting in a sum value. Two of the identified leaks located on the top of one reactor (at the biomass stirrer and pressure relief valve) were not quantified by the on-site team due to technical difficulties, and they were thus not included in the estimation of total 
$\mathrm{CH}_{4}$ emissions using the on-site approach. The sum of $\mathrm{CH}_{4}$ emission rates from on-site sources was $3.4 \mathrm{~kg} \mathrm{CH}_{4} \mathrm{~h}^{-1}$ (Table 2), with the majority (86\%) originating from just four of the 13 identified emission sources (Fig. 1). The largest individual source of $\mathrm{CH}_{4}$ emission from biogas plant $\mathrm{A}$ was the gas engine, comprising $45 \%$ of all sources (Table 2). The second largest source of $\mathrm{CH}_{4}$ emission was building ventilation, led through a biofilter for odour control $(26 \%)$. This source was quantified by measuring the $\mathrm{CH}_{4}$ concentration at the inlet to the biofilter, and multiplying the concentration with the air flow, which was determined from the specifications of the blower leading air to the biofilter. The choice to measure methane flow at the inlet to the biofilter as opposed to the outlet was done by the measurement team for practical reasons. The biofilter may potentially have some $\mathrm{CH}_{4}$ oxidation capability. However, due to low retention of the gas in biofilters for odour reduction, $\mathrm{CH}_{4}$ oxidation is expected to be minor, and thus the choice of measuring before the filter inlet is not expected to have led to any significant overestimation of this emission source. The main sources of this $\mathrm{CH}_{4}$ flow were found to be from two pipes located in the biomass-receiving building (inlets from manure transport), while two other sources were ventilation from the gas building and the compressor building, accounting for $6.9 \%$ and $7.0 \%$, respectively, of the combined emissions identified by on-site measurements. Leaks at pressure relief valves on the digesters were also found to emit $\mathrm{CH}_{4}$, albeit they only contributed to a relatively low proportion in this regard.

The sum of emission rates from biogas plant $\mathrm{A}$, determined using the on-site approach $\left(3.4 \mathrm{~kg} \mathrm{CH}_{4}\right.$ $\mathrm{h}^{-1}$ ), was lower than the total $\mathrm{CH}_{4}$ emission rate determined using the TDM, where the average rate on the two measurement days was $5.5 \mathrm{~kg} \mathrm{CH}_{4} \mathrm{~h}^{-1}$. One reason for this difference may be the two identified leaks on the top of the reactor that were not quantified, as well as other leaks not found during the initial search. The calculation method used to estimate the $\mathrm{CH}_{4}$ emission rate from the gas engine was a contributor to uncertainty, in that the fraction of un-combusted $\mathrm{CH}_{4}$ may vary from engine to engine (Liebetrau et al., 2013), and a default value of $1.7 \%$ was used herein, as 
described in section 2.3.5. Another reason may be variations over time in the true emission rate. During the second day of measurement, total $\mathrm{CH}_{4}$ emissions measured using TDM were considerably higher $\left(9.5 \mathrm{~kg} \mathrm{CH}_{4} \mathrm{~h}^{-1}\right.$, an average of 21 plume traverses) than on the first day $(3.3 \mathrm{~kg}$ $\mathrm{CH}_{4} \mathrm{~h}^{-1}$, average of 37 plume traverses). According to the plant operators, technical problems with one of the pumps at the plant may have caused gas pressure build-up, which may in turn have led to a higher emission rate on the second day due to emission through pressure relief valves.

We note that $\mathrm{CH}_{4}$ emissions from the off-site $\mathrm{CHP}$ units receiving gas from biogas plant $\mathrm{A}$ were not quantified in this study, and that these emissions are therefore not included in the results listed in Table 2.

\subsection{Methane emissions from biogas plant $B$}

Relatively few leakages were found at biogas plant B, with the leakage search using optical imaging to identify nine sources of $\mathrm{CH}_{4}$ emission, each of which was quantified (Fig. 1). These emission sources were open digestate storage tanks, pressure relief valves, near to the supply to the CHP unit, a manhole cover and a sludge pump tank. Emissions from pressure relief valves were not from pressure relief events, but leakages from closed valves. Additionally, $\mathrm{CH}_{4}$ was emitted from the exhaust of the gas engine at the site, which the on-site team was not asked to include in their measurements but was subsequently estimated as described in section 2.3.5.

The largest source of $\mathrm{CH}_{4}$ emission at biogas plant $\mathrm{B}$ was found to be the open digestate storage tanks at $53 \%$ of the total sum. This result is in line with previous studies on $\mathrm{CH}_{4}$ emissions from facilities with open digestate storage tanks (Liebetrau et al., 2013; Reinelt et al., 2017). As described in section 2.3.4, quantification from this source was not done by measurement but was instead calculated by assuming that $\mathrm{CH}_{4}$ formation and its subsequent emission were equivalent to $\mathrm{CH}_{4}$ emissions in the digesters. The validity of this assumption was not tested, and so we consider 
this estimation to be potentially highly uncertain. Another major source of $\mathrm{CH}_{4}$ emission was the CHP unit, from where $38 \%$ of the sum of quantified on-site sources originated. Other sources of emission from biogas plant $\mathrm{B}$, including leaks from the pressure relief valves, were found to be of lesser importance (Table 2).

The sum of emission rates measured from biogas plant B (on-site approach) was $6.5 \mathrm{~kg} \mathrm{CH}_{4} \mathrm{~h}^{-1}$. As for biogas plant $\mathrm{A}$, the sum of quantified on-site sources of $\mathrm{CH}_{4}$ emission at biogas plant $\mathrm{B}$ was significantly lower than that measured using TDM, which was $13.5 \mathrm{~kg} \mathrm{CH}_{4} \mathrm{~h}^{-1}$ (Table 2). The reasons for this difference may be quantification uncertainties, variations in the true emission rate and unidentified $\mathrm{CH}_{4}$ sources not quantified by the on-site team, or a combination of these factors. Another possibility was interference from a wastewater treatment plant adjacent to the biogas plant. During screening of $\mathrm{CH}_{4}$ concentrations in the atmosphere at the biogas plant, concentrations up to $5.25 \mathrm{ppm} \mathrm{CH}_{4}$ above background level were observed, where the highest concentrations were measured near the open digestate storage tanks. At the area with wastewater treatment reactors, concentrations were up to $0.5 \mathrm{ppm}$ above background level. The $\mathrm{CH}_{4}$ concentration screening thus suggested that the emission of $\mathrm{CH}_{4}$ from the biogas plant was higher than the emission from the wastewater treatment area. A previous study at the same biogas plant/wastewater treatment plant also showed that the most significant $\mathrm{CH}_{4}$ emissions emanated from areas around the digesters (Yoshida et al., 2014). The emission rates quantified in this study were within the range reported for the same facility (5 to $32 \mathrm{~kg} \mathrm{CH}_{4} \mathrm{~h}^{-1}$ when excluding measurements performed during digester malfunction (92 $\left.\mathrm{kg} \mathrm{CH}_{4} \mathrm{~h}^{-1}\right)$ ) (Yoshida et al., 2014).

\subsection{Methane emissions from biogas plant $\mathrm{C}$}

The leakage search at biogas plant $\mathrm{C}$, using a portable $\mathrm{CH}_{4}$ gas analyser supplemented with optical imaging, found eight sources of emission that required quantification (Fig. 1). Four of those were at 
the biogas upgrade unit at this site, whereas two were found to be ventilation air from a biomass receiving tank and a biomass mixing tank. The remaining two sources were leakages from a digestate/gas storage tank (safety vent and air outlet).

All identified emission sources at biogas plant $C$ were quantified, with the highest emission rate measured at the $\mathrm{CO}_{2}$ exhaust from the water scrubber used for biogas upgrading. According to the plant operator, gas production from this newly constructed biogas plant had exceeded the designed capacity for the upgrade unit, thus leading to excessive $\mathrm{CH}_{4}$ loss through the $\mathrm{CO}_{2}$ exhaust from the water scrubber, and the biogas upgrading unit itself requiring modification or replacement with a higher capacity element. The $\mathrm{CH}_{4}$ emission rate from the biogas upgrade unit accounted for $75 \%$ of the sum of on-site source emissions.

Ventilation from the biomass mixing tank and biomass receiving tank comprised $22 \%$ of emissions, whereas the two leaks found at a digestate/gas storage tank were of lesser importance (3\%).

The sum of the measured on-site sources of $\mathrm{CH}_{4}$ emission was $27.8 \mathrm{~kg} \mathrm{CH}_{4} \mathrm{~h}^{-1}$, whereas the average total from biogas plant $\mathrm{C}$ was measured at $12.6 \mathrm{~kg} \mathrm{CH}_{4} \mathrm{~h}^{-1}$ using the TDM. The fact that the sum of emissions using the on-site approach was higher than the TDM results was surprising. One possibility was that the results of the TDM measurement were lower than the true emission rate, due to incomplete tracer and $\mathrm{CH}_{4}$ gas mixing. On-site measurements showed that a large part of leakage from the site occurred through a chimney, including $\mathrm{CO}_{2}$ release from the water scrubber. Since the tracer gas was released near ground level, incomplete $\mathrm{CH}_{4}$ and tracer gas mixing of in this case would have led to an underestimation of the $\mathrm{CH}_{4}$ emission rate using the TDM. This possibility was evaluated by using a Gaussian plume model similar to an approach used in previous studies (Delre et al., 2017; Yoshida et al., 2014). The model results suggested that underestimation due to the emission height difference of $\mathrm{CH}_{4}$ and tracer gasses was not likely to explain sufficiently 
differences in relation to weather conditions during measurement (Pasquill stability class B - slight insulation), measurement distance (up to $1200 \mathrm{~m}$ ) and the height of the chimney ( $35 \mathrm{~m})$. Two roads were used to perform the TDM measurements, and the distances between the chimney and the observed peak concentrations were $400 \mathrm{~m}$ and $1300 \mathrm{~m}$, respectively. Using the closer of the two roads led to an underestimation of the $\mathrm{CH}_{4}$ emission rate of $22 \%$, according to the dispersion model, whereas using the road farther away led to an underestimation of $3 \%$. The average emission rate using the road farthest away for TDM measurement was somewhat higher than the value for the closer road (14.5 and $12.1 \mathrm{~kg} \mathrm{CH}_{4} \mathrm{~h}^{-1}$, respectively), which is consistent with the more significant underestimation using the TDM along this route. Another explanation for the observed difference between on-site quantification and the TDM results was the variation in the true $\mathrm{CH}_{4}$ emission rate at biogas plant C. Fig. 2 shows total $\mathrm{CH}_{4}$ emissions measured for each plume traverse at biogas plant $\mathrm{C}$ using the TDM, suggesting that emissions varied between $\sim 5$ and $35 \mathrm{~kg} \mathrm{CH}_{4} \mathrm{~h}^{-1}$ on the measurement day. Note that measurement uncertainty for the emission rates determined using TDM for single-plume traverses should be considered higher compared to TDM measurements reporting average values of several plume traverses (Fredenslund et al., 2018; Mønster et al., 2014). Quantification of the largest point source of $\mathrm{CH}_{4}$ emission $\left(\mathrm{CO}_{2}\right.$ exhaust from the water scrubber) was done over a 20-minute period, one hour before the TDM measurements were initiated. This emission occurred through a pipe, where the gas flow rate was determined using a pitot tube/micro manometer, and the $\mathrm{CH}_{4}$ concentration was measured using a FID (section 2.3.3). Since measurement of this dominant, single source of $\mathrm{CH}_{4}$ emission and the TDM measurements did not occur simultaneously, emission dynamics may explain the difference in measured emission rates between the on-site and TDM approaches. No further explanations such as change in operation of the water scrubber, signs of erroneous measurement of the FID used to measure $\mathrm{CH}_{4}$ from the water 
scrubber or similar, were found to explain the difference between TDM measurements and $\mathrm{CH}_{4}$ emission from this dominant, single source.

\subsection{Methane emissions from biogas plant $D$}

An IR camera leakage search found 19 sources of $\mathrm{CH}_{4}$ emission at biogas plant $\mathrm{D}$, four of which were ventilation air from a biomass receiving tank, a mixing tank, a biomass heating unit and a biogas upgrade unit leading to a biofilter set up for odour control. The quantification of these four sources was done collectively by measuring air flow and $\mathrm{CH}_{4}$ concentration at the inlet to the biofilter. Individual measurements for these four sources were also performed, indicating that 94\% of the $\mathrm{CH}_{4}$ leading to the biofilter was from the receiving and the mixing tanks. On-site measurements disclosed that $\mathrm{CH}_{4}$ in the ventilation air leading to the biofilter constituted $84 \%$ of the total sum of quantified on-site sources, whereby ventilation air was the most significant contributor to $\mathrm{CH}_{4}$ emissions. Other emission sources consisted of leaks from pressure relief valves (5\% of on-site measured emission), various minor leaks from caps, edges of soft covers and other (9\%) and ventilation from the gas building (2\%). Two leaks at the top of a biomass storage tank that were identified using the IR camera were not quantified due to inaccessibility.

The sum of on-site quantified $\mathrm{CH}_{4}$ emission rates was $15.4 \mathrm{~kg} \mathrm{CH}_{4} \mathrm{~h}^{-1}$, which was close to the measured total $\mathrm{CH}_{4}$ emission rate using TDM $\left(13.5 \mathrm{~kg} \mathrm{CH}_{4} \mathrm{~h}^{-1}\right)$. Several reasons may explain the closer results of the on-site and TDM quantifications at biogas plant D. First, the digesters, tanks, etc. were much lower and wider compared to the other facilities, which may have increased the likelihood of detecting leakages, due to better accessibility. Second, all on-site quantifications were based on measurements, whereas the use of the calculation methods for estimating $\mathrm{CH}_{4}$ losses from engines and open digestate storage at plants A and B may have increased the uncertainty of the onsite quantifications at these locations. Last, TDM measurements at biogas plant D suggested a 
comparatively lower variation in total $\mathrm{CH}_{4}$ emissions from this site. The observed sample standard deviation was $2.5 \mathrm{~kg} \mathrm{CH}_{4} \mathrm{~h}^{-1}$ using TDM (or $19 \%$ of the average emission), while in comparison, for plant $\mathrm{C}$, the rate was $6.0 \mathrm{~kg} \mathrm{CH}_{4} \mathrm{~h}^{-1}$ (or $48 \%$ of the average emissions). A more constant, actual $\mathrm{CH}_{4}$ emission rate from biogas plant D may therefore explain the higher similarity between the onsite and TDM measured $\mathrm{CH}_{4}$ emission rates.

\subsection{Identified $\mathrm{CH}_{4}$ emission mitigation options}

Based on on-site measurements, emission mitigation options at the four biogas plants $\mathrm{CH}_{4}$ were suggested. At biogas plant A, it was recommended that compressors and a blower unit in a gas building should be renovated to reduce leakage and that pressure relief valves should be checked regularly. Eliminating leakage from the gas compressor and the blower unit would result in a reduction in emissions of $0.47 \mathrm{~kg} \mathrm{CH}_{4} \mathrm{~h}^{-1}(\sim 14 \%)$, according to the on-site quantification of these leakages. For biogas plant B, it was recommended that the open digestate storage should be closed off and fitted with a gas collection apparatus. Here, it was also recommended that a sludge pump tank be enclosed to reduce leakage. Eliminating these sources of emission would lead to a reduction of $3.6 \mathrm{~kg} \mathrm{CH}_{4} \mathrm{~h}^{-1}(\sim 56 \%)$. For biogas plant $\mathrm{C}$, it was recommended that a thermal oxidiser should be installed to reduce $\mathrm{CH}_{4}$ emissions from the biogas upgrade unit, thereby eliminating emissions from this source and leading to a reduction in emissions of $20.9 \mathrm{~kg} \mathrm{CH}_{4} \mathrm{~h}^{-1}(\sim 75 \%)$. The biogas upgrade unit was later replaced with a chemical scrubber with adequate capacity, which likely caused a significant reduction in $\mathrm{CH}_{4}$ emissions. In addition, a hole in a pipe was found, which was recommended for repair. It was also recommended to perform maintenance on a safety vent and air outlet at a digestate/gas storage unit. Finally, for biogas plant D, it was recommended to look into utilising gas from the receiving and mixing tanks in the biogas upgrade unit. Eliminating emissions from those tanks would result in a reduction in $\mathrm{CH}_{4}$ emissions of $12.7 \mathrm{~kg} \mathrm{CH}_{4} \mathrm{~h}^{-1}(\sim 83 \%)$. It was 
also recommended to perform maintenance on various valves and fittings, to reduce minor leakages, and to replace a piece of piping, the type of which was deemed to be leading to $\mathrm{CH}_{4}$ emissions.

\subsection{Comparison of the on-site vs. the remote sensing approach}

The sum of $\mathrm{CH}_{4}$ emission rates from on-site quantification varied for total $\mathrm{CH}_{4}$ emission rates measured using TDM on the same measurement days. The largest differences were observed at biogas plants $\mathrm{B}$ and $\mathrm{C}$, where one rate was $\sim 100 \%$ larger than the value of the other rate in both of these cases. As discussed in section 3.4, several factors may have caused these observed differences, apart from measurement uncertainties. These include sources of emission that were undetected, and therefore not included in the on-site quantification, sources of emission that were difficult/impossible to quantify for several reasons and short-term dynamics in the true $\mathrm{CH}_{4}$ emission rate.

Since on-site quantification, in practice, should be done one source at a time, emissions from one source are only typically measured over a period of 10-20 minutes, which may cause the TDM to be less sensitive to short-term dynamics in emission rates, since the longer measurement time may include periods of both high and low emission. Both of our results, and previous studies, suggest that emission rates from biogas plants vary in the short term (Baldé et al., 2016; Groth et al., 2015; Yoshida et al., 2014). If, for example, ten leaks are found at a biogas plant which need to be quantified, and each of these leaks is measured over ten minutes, it would be possible to perform 100 minutes of measurement using TDM, even without considering the additional time required to move on-site equipment from one location to the next. Our results suggest that $\mathrm{CH}_{4}$ emissions at biogas plants can have single emission sources, which contribute to $75 \%$ of the total emission rate, such as the $\mathrm{CO}_{2}$ exhaust from the water scrubber at biogas plant $\mathrm{C}$. If that source of emission varied in the short term, as the variation in the total emission rate using TDM, shown in Fig. 2, may 
suggest, it may be beneficial to perform measurement over a longer period. The TDM is the most efficient option to measure the total plant emission over a longer period, but in the case of a single or few dominant sources (such as the water scrubber at biogas plant C) are identified, it may be beneficial to perform long-term measurement of the emission from that/those source(s), if the onsite approach is chosen.

At all four biogas plants, most of the $\mathrm{CH}_{4}$ emissions occurred from a few dominant sources (Fig. 1). It is thus highly important that these sources are identified using the on-site approach, as well as to ensure that emission rates from these dominant sources can be measured in such a way to avoid reliance on uncertain estimates, such as for open digestate storage at plant $\mathrm{B}$, where $\mathrm{CH}_{4}$ potential for the digested sludge was used to estimate emissions.

Comparing measured emission rates to gas production for each facility (provided from each biogas plant's supervisory control and data acquisition SCADA system), relative methane losses $\left(\mathrm{CH}_{4}\right.$ emission/ $\mathrm{CH}_{4}$ production) were calculated. Measured losses using the TDM method ranged from 1.4 to $8.4 \%$ of production (Table 2). The summed average (sum of emissions, four plants/sum of production, four plants) was $2.7 \%$, which is comparable to losses of $3.1 \%$ reported from an agricultural digester (Flesch et al., 2011), and 0.6 to 2.1\% from a sludge digester (Reinelt et al., 2017).

One drawback of TDM is that it does not pinpoint or quantify individual sources of emission. If the purpose of measuring $\mathrm{CH}_{4}$ emissions at a biogas plant is to find mitigation options, and thereby provide options to improve the environmental benefits of biogas production, on-site methods are needed. Conversely, a downside to the on-site quantification methods described in this paper is that quantification may be comparatively time-consuming - especially at large facilities, where 
numerous sources of emission are found and might be overlooked, with some technically unquantifiable points of leakage leading to an underestimation of the plant's total $\mathrm{CH}_{4}$ emission.

Our results therefore suggest that on-site and remote sensing methods cannot substitute each other, if both an accurate assessment of the total emission rate and the identification of mitigation options are required. A strategy of combining quick, semi-quantitative on-site measurements and TDM or similar remote sensing methods may be effective in achieving both aims, which may be the subject of further development.

\subsection{Allocating $\mathrm{CH}_{4}$ emissions to gas production}

Both gas production and gas utilisation occurred at all four biogas plants in this study. Gas utilisation is defined here as either use in CHP units or conversion to biomethane in biogas upgrade units. Since on-site measurements were performed, it was possible to allocate $\mathrm{CH}_{4}$ emissions to either gas production or utilisation. At biogas plant A, the sum of quantified on-site sources was 3.4 $\mathrm{kg} \mathrm{CH}_{4} \mathrm{~h}^{-1}$, of which $43 \%$ was estimated to be from the on-site CHP unit. Subtracting the gas engine emission $\left(1.5 \mathrm{~kg} \mathrm{CH}_{4} \mathrm{~h}^{-1}\right)$ from the total plant emission determined by TDM measurements and sum of on-site sources, the emission related to gas production alone can be estimated at $1.9 \mathrm{~kg}$ $\mathrm{CH}_{4} \mathrm{~h}^{-1}$ and $4.0 \mathrm{~kg} \mathrm{CH}_{4} \mathrm{~h}^{-1}$ respectively, if it is assumed that all other emission than from the CHP unit can be allocated to gas production. These emission estimates equalled $0.5 \%$ and $1.0 \%$ of the gas production, respectively. Similarly, emission from gas production from biogas plant B can be estimated at $4.0 \mathrm{~kg} \mathrm{CH}_{4} \mathrm{~h}^{-1}$ (on-site method) and $11.0 \mathrm{~kg} \mathrm{CH}_{4} \mathrm{~h}^{-1}$ (TDM) or $2.5 \%$ and $6.8 \%$ of the production. At biogas plant $\mathrm{C}$, the gas utilisation (water scrubber) was found to be the dominant source (section 3.3), where the emission rate was found to be higher than the total emission from the biogas plant measured later using TDM. Allocating emissions to gas production by subtracting emission from the water scrubber from the sum of on-site emission sources, the emission from gas 
production at biogas plant $\mathrm{C}$ is estimated to be $6.9 \mathrm{~kg} \mathrm{CH}_{4} \mathrm{~h}^{-1}$ equal to $1.0 \%$ of the gas production. At biogas plant $\mathrm{D}$, the on-site measurement team did not observe $\mathrm{CH}_{4}$ emission from the chemical scrubber, whereby all emission from that biogas plant can be allocated to gas production.

\section{Conclusion}

Methane $\left(\mathrm{CH}_{4}\right)$ emissions from four biogas plants were measured on the same days, using both onsite quantification methods and TDM. In general, $\mathrm{CH}_{4}$ emission rates were between 5.5 and $13.5 \mathrm{~kg}$ $\mathrm{CH}_{4} \mathrm{~h}^{-1}$, using TDM corresponding to $1.4-8.3 \%$ of the $\mathrm{CH}_{4}$ production. On-site measurements showed that the majority (> 80\%) of the emissions often occurred from a few sources (between two and four sources). Our results suggest that on-site and TDM measurements cannot replace each other if accurate measurements of the total $\mathrm{CH}_{4}$ emission rate as well as the identification of $\mathrm{CH}_{4}$ emission mitigation options are necessary.

E-supplementary data for this work can be found in the online version of this paper.

\section{Acknowledgements}

The Danish Energy Agency is acknowledged for partially funding the measurement campaigns. We thank the owners and personnel at the biogas plants for their cooperation as well as funding, and we thank Torben Kvist at the Danish Gas Technology Centre for coordinating the project.

\section{References}

1. Baldé, H., VanderZaag, A.C., Burtt, S.D., Wagner-Riddle, C., Crolla, A., Desjardins, R.L., MacDonald, D.J., 2016. Methane emissions from digestate at an agricultural biogas plant. Bioresour. Technol. 216, 914-922. https://doi.org/10.1016/j.biortech.2016.06.031

2. Clemens, J., Trimborn, M., Weiland, P., Amon, B., 2006. Mitigation of greenhouse gas emissions 
by anaerobic digestion of cattle slurry. Agric. Ecosyst. Environ. 112, 171-177. https://doi.org/10.1016/j.agee.2005.08.016

3. Delre, A., Mønster, J., Samuelsson, J., Fredenslund, A.M., Scheutz, C., 2018. Emission quantification using the tracer gas dispersion method: The influence of instrument, tracer gas species and source simulation. Sci. Total Environ. 634, 59-66. https://doi.org/10.1016/j.scitotenv.2018.03.289

4. Delre, A., Mønster, J., Scheutz, C., 2017. Greenhouse gas emission quantification from wastewater treatment plants, using a tracer gas dispersion method. Sci. Total Environ. 605606, 258-268. https://doi.org/10.1016/j.scitotenv.2017.06.177

5. Energistyrelsen, Energinet.dk, 2017. Technology Data for Energy Plants - August 2016 (Update June, October and November 2017) 157. https://doi.org/ISBN: 978-87-7844-940-5

6. Flesch, T.K., Desjardins, R.L., Worth, D., 2011. Fugitive methane emissions from an agricultural biodigester. Biomass and Bioenergy 35, 3927-3935. https://doi.org/10.1016/j.biombioe.2011.06.009

7. Fredenslund, A.M., Rees-White, T.C., Beaven, R., Delre, A., Finlayson, A., Helmore, J., Allen, G., Scheutz, C., 2018. Controlled release validation of the mobile tracer gas dispersion method for measurement of fugitive emissions from area sources. Waste Manag. (submitted.

8. Groth, A., Maurer, C., Reiser, M., Kranert, M., 2015. Determination of methane emission rates on a biogas plant using data from laser absorption spectrometry. Bioresour. Technol. 178, 359361. https://doi.org/10.1016/j.biortech.2014.09.112

9. Liebetrau, J., Reinelt, T., Clemens, J., Hafermann, C., Friehe, J., Weiland, P., 2013. Analysis of greenhouse gas emissions from 10 biogas plants within the agricultural sector. Water Sci. 
Technol. 67, 1370-1379. https://doi.org/10.2166/wst.2013.005

10. Meyer-Aurich, A., Schattauer, A., Hellebrand, H.J., Klauss, H., Pl??chl, M., Berg, W., 2012. Impact of uncertainties on greenhouse gas mitigation potential of biogas production from agricultural resources. Renew. Energy 37, 277-284.

https://doi.org/10.1016/j.renene.2011.06.030

11. Møller, J., Boldrin, A., Christensen, T.H., 2009. Anaerobic digestion and digestate use: accounting of greenhouse gases and global warming contribution. Waste Manag. Res. 27, 813824. https://doi.org/10.1177/0734242X09344876

12. Mønster, J., Samuelsson, J., Kjeldsen, P., Scheutz, C., 2015. Quantification of methane emissions from 15 Danish landfills using the mobile tracer dispersion method. Waste Manag. 35, 177-186. https://doi.org/10.1016/j.wasman.2014.09.006

13. Mønster, J.G., Samuelsson, J., Kjeldsen, P., Rella, C.W., Scheutz, C., 2014. Quantifying methane emission from fugitive sources by combining tracer release and downwind measurements - A sensitivity analysis based on multiple field surveys. Waste Manag. 34, 1416-1428. https://doi.org/10.1016/j.wasman.2014.03.025

14. Reinelt, T., Delre, A., Westerkamp, T., Holmgren, M.A., Liebetrau, J., Scheutz, C., 2017. Comparative use of different emission measurement approaches to determine methane emissions from a biogas plant. Waste Manag. 68, 173-185. https://doi.org/10.1016/j.wasman.2017.05.053

15. Reinelt, T., Liebetrau, J., Nelles, M., 2016. Analysis of operational methane emissions from pressure relief valves from biogas storages of biogas plants. Bioresour. Technol. 217, 257-264. https://doi.org/10.1016/j.biortech.2016.02.073 
16. Sommer, S.G., Petersen, S.O., Moeller, H.B., 2004. Algorithms for calculating methane and nitrous oxide emissions from manure management. Nutr. Cycl. Agroecosystems 69, 143-154. https://doi.org/10.1023/B:FRES.0000029678.25083.fa

17. Yoshida, H., Mønster, J., Scheutz, C., 2014. Plant-integrated measurement of greenhouse gas emissions from a municipal wastewater treatment plant. Water Res. 61, 108-118. https://doi.org/10.1016/j.watres.2014.05.014 


\section{FIGURE CAPTIONS}

Fig. 1. $\mathrm{CH}_{4}$ emission rates measured on identified emission sources (or group of sources) at the four biogas plants (plants A, B, C and D), using the on-site approach.

Fig. 2. Total $\mathrm{CH}_{4}$ emission rates from biogas plant $\mathrm{C}$ (single-plume traverses), determined using TDM. 


\section{TABLES}

Table 1. Main characteristics of the four biogas plants

\begin{tabular}{|c|c|c|c|c|}
\hline $\begin{array}{l}\text { Biogas } \\
\text { plant }\end{array}$ & Feedstocks & $\begin{array}{l}\text { Gas production } \\
\left(\text { million } \mathrm{kg} \mathrm{CH}_{4} \mathrm{yr}^{-1}\right)\end{array}$ & Gas utilisation & $\begin{array}{l}\text { CHP unit(s), total } \\
\text { capacity (MW) }\end{array}$ \\
\hline A & Manure, organic waste & 3.4 & $\begin{array}{l}\text { CHP on-site }(\sim 20 \%), \\
\text { CHP off-site }(\sim 80 \%)\end{array}$ & $\begin{array}{l}1 \times 1.35 \text { (on-site) } \\
2 \times 2.65 \text { (off-site) }\end{array}$ \\
\hline B & Wastewater sludge & 1.4 & CHP on-site & 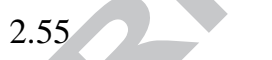 \\
\hline $\mathrm{C}$ & $\begin{array}{l}\text { Manure, slaughterhouse } \\
\text { waste }\end{array}$ & 4.6 & $\begin{array}{l}\text { Upgrade to bio- } \\
\text { methane (water } \\
\text { scrubber) on-site }\end{array}$ & \\
\hline $\mathrm{D}$ & $\begin{array}{l}\text { Manure, straw, maize } \\
\text { silage }\end{array}$ & 2.9 & $\begin{array}{l}\text { Upgrade to bio- } \\
\text { methane (chemical } \\
\text { scrubber) on-site }\end{array}$ & \\
\hline
\end{tabular}


Table 2. Measured $\mathrm{CH}_{4}$ emission rates using TDM and on-site methods

\begin{tabular}{|c|c|c|c|c|c|}
\hline $\begin{array}{l}\text { Biogas } \\
\text { plant }\end{array}$ & $\begin{array}{l}\text { Total } \mathrm{CH}_{4} \\
\text { emission - } \\
\text { TDM } \\
\text { measurement } \\
\\
\text { (kg CH}_{4} \mathrm{~h}^{-1} \text {; } \\
\text { fraction of } \\
\text { gas } \\
\text { production) }\end{array}$ & $\begin{array}{l}\text { Number of } \\
\text { plume } \\
\text { traverses } \\
\text { (TDM) }\end{array}$ & $\begin{array}{l}\mathrm{CH}_{4} \text { emission } \\
\text { - sum of } \\
\text { individual } \\
\text { sources } \\
\left(\mathrm{kg} \mathrm{CH}_{4} \mathrm{~h}^{-1} ;\right. \\
\text { fraction of gas } \\
\text { production) }\end{array}$ & $\begin{array}{l}\text { Number of } \\
\text { individual } \\
\text { sources } \\
\text { identified, } \\
\text { quantified }\end{array}$ & $\begin{array}{l}\text { On-site measurement - emission } \\
\text { sources (percentage of the sum of } \\
\text { individual sources) }\end{array}$ \\
\hline $\mathrm{A}^{\mathrm{b}}$ & $\begin{array}{l}5.5 \pm 0.7 \\
1.4 \%\end{array}$ & 58 & $3.4 ; 0.8 \%$ & 22,20 & $\begin{array}{l}\text { Gas engine }(45.1 \%) \text {; Leaks at } \\
\text { pressure relief valves }(6.8 \%) \text {; } \\
\text { Ventilation from building through } \\
\text { biofilter (26.4\%), Leaks at } \\
\text { biomass stirrers (1.4\%); Gas } \\
\text { compressor, gas measurement } \\
\text { unit and other }(20.2 \%)\end{array}$ \\
\hline B & $\begin{array}{l}13.5 \pm 0.5 \\
8.3 \%\end{array}$ & 21 & $6.5 ; 4.0 \%$ & 10,10 & $\begin{array}{l}\text { Open digestate storage }(53.1 \%) \text {; } \\
\text { Gas engine }(38.3 \%) \text {; Leaks at } \\
\text { pressure relief valves }(2.6 \%) \text {; Gas } \\
\text { booster, ventilation from engine } \\
\text { building and other }(6.0 \%)\end{array}$ \\
\hline $\mathrm{C}$ & $\begin{array}{l}12.6 \pm 0.9 \\
1.9 \%\end{array}$ & 49 & -7 & 8,8 & $\begin{array}{l}\text { Biogas upgrade unit }(75.3 \%) \text {; } \\
\text { Ventilation from biomass mixing } \\
\text { tank and biomass receiving tank } \\
(21.7 \%) \text {; Leaks at safety vent and } \\
\text { air outlet at digestate/gas storage } \\
\text { unit }(2.5 \%)\end{array}$ \\
\hline $\mathrm{D}$ & $\begin{array}{l}13.4 \pm 0.5 \\
3.3 \%\end{array}$ & 28 & $8 \%$ & 19,16 & $\begin{array}{l}\text { Gas outlets from receiving tank, } \\
\text { mixing tank and ventilation to } \\
\text { biofilter }(83.6 \%) \text {, Leaks at } \\
\text { pressure relief valves }(5.5 \%) ; \\
\text { Ventilation from gas building } \\
(1.7 \%) \text {; Leaks at caps and other } \\
(9.2 \%)\end{array}$ \\
\hline
\end{tabular}

${ }^{\mathrm{a}}$ Uncertainty is estimated as a standard error of the mean (see section 2.2)

${ }^{\mathrm{b}} \mathrm{CH}_{4}$ emissions from off-site CHP units were not included 
A

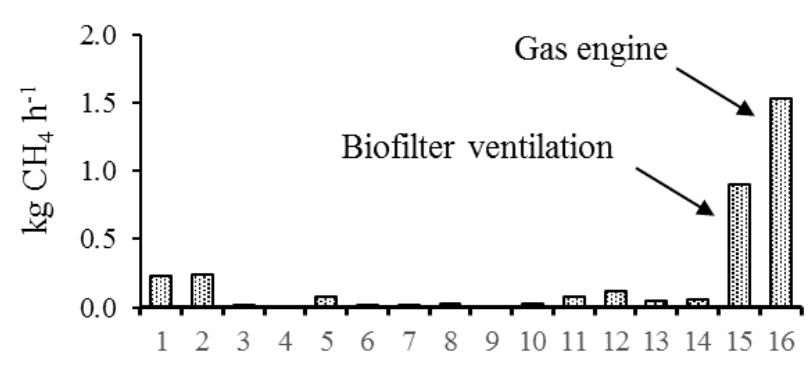

C

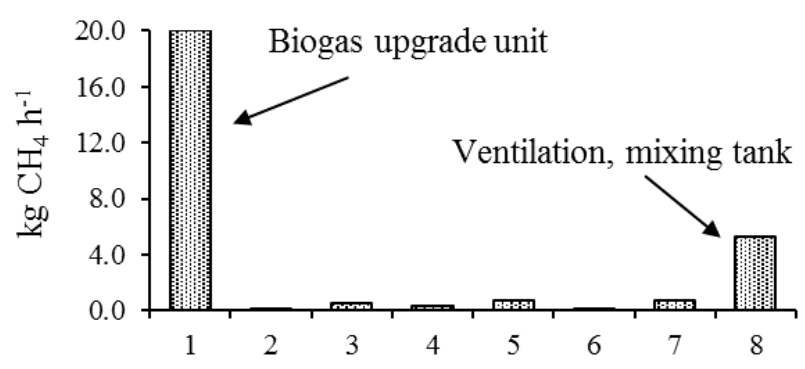

\section{B}

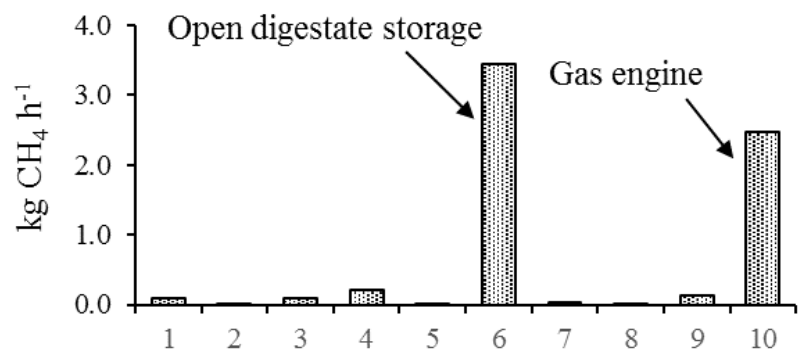

D

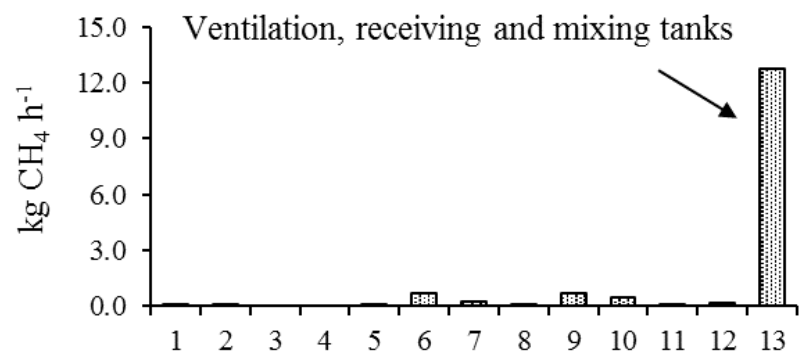

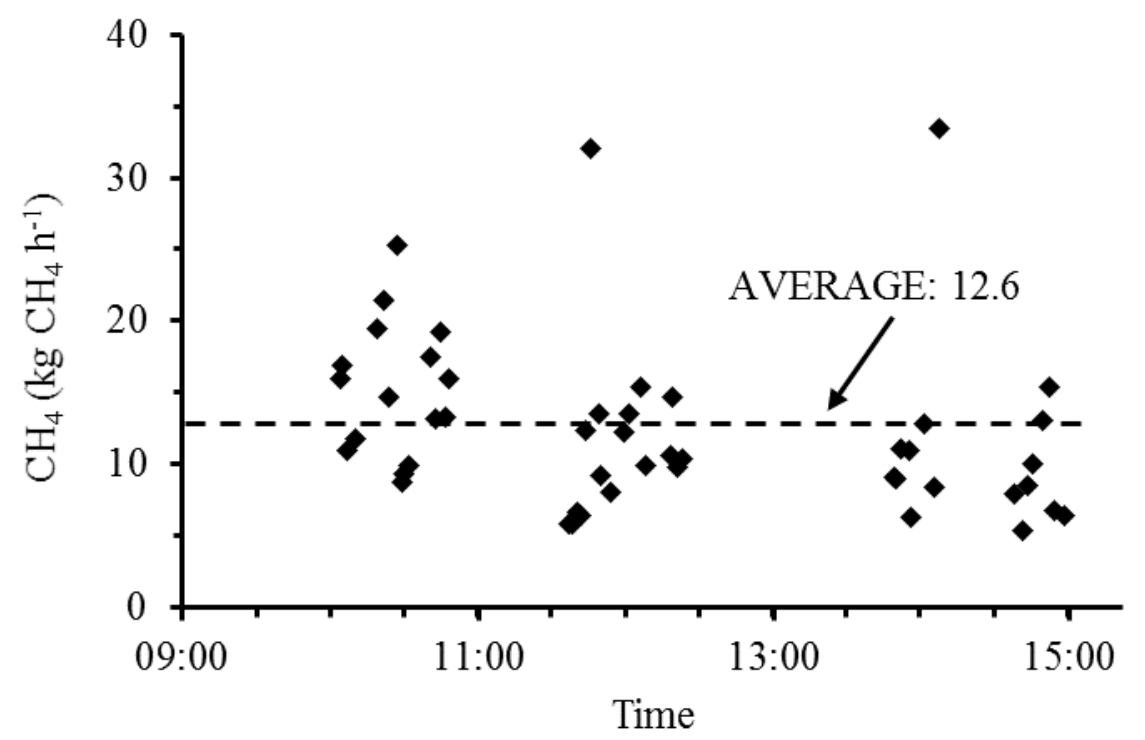




\section{Highlights}

- Same-day, on-site and remote sensing emission measurements for four biogas plants

- Remote sensing methane emission rates varied from summed on-site emission rates

- On-site methods can identify key points of leakage

- On-site measurements may not include all emission sources 